according to the older (say Newtonian) definition. In particular, the function to be integrated might have a finite number of isolated discontinuities in the range of integration; isolated, that is, in the sense of being separated by finite intervals. Thus a new type of integrals, the Riemann integrals, had come under observation.

Quite recently the whole theory of integration has entered upon a new phase, mainly through the development of the theory of sets of points, and the enlarged notion of "function" now established. To Lebesgue is due a definition of a definite integral which is applicable in certain cases even when Rienrann's is not. The Lebesgue integral agrees in value with the Riemann integral when the latter exists; just as the Riemann integral agrees in value with the ordinary integral when the latter exists. The very latest contributions to the theory are mainly due to Vallée Poussin and Baire, and apparently a kind of finality has been reached in the mathematical notion of an integral, at least in the light of our present mathematical knowledge. Students will find an excellent summary in Prof. G. A. Bliss's lecture, "Integrals of Lebesgue," published in the Bulletin of the American Mathematical Society for October, rqI7. The reader must have a fair acquaintance with the theory of sets (including the notions of measure and content); otherwise the lecture is self-contained. References to recent works on the subject are also given.

Few things are more remarkable than the mathematical discoveries of the present generation, discoveries which have profoundly affected the very rudiments and foundations of logic, analysis, and geometry. They cannot be ignored even by the elementary teacher, and the problem of making them familiar to students is one that must be resolutely faced.

G. B. M.

\section{METEOROLOGY IN THE ARGENTINE} REPUBLIC

$\triangle$ COPY has reached us of the Boletin Mensual of the Argentine Meteorological Office-a new monthly weather review that has now been running for more than a year. The data summarised refer to the year 19I6, and are given in useful form. The tri-daily meteorological observations for twenty-five stations are printed in extenso, and an abstract of these, along with returns from other fifty-two stations, are given in an extended table. The elements summarised are pressure, temperature, relative and absolute humidity, direction of the wind, rainfall, cloud, and the number of frosts experienced.

The stations range in latitude from $55^{\circ} \mathrm{S}$. to $22^{\circ} \mathrm{S}$. and in height from 4 to 3447 metres, so that all climates are represented. Tables of daily rainfall are given for more than 1400 stations. "The distribution, as is to be expected in a country like Argentina, where the meteorological posts are in general also railway stations, is very irregular. In the province of Buenos Aires, which embraces an area equal to that of the United Kingdom without Wales, there are 556 raingauge stations, but in the equally large territory of Santa Cruz there are only eleven stations. The results are shown in six coloured maps, giving the rainfall, the departure of the rainfall from the average, the accumulated rainfall since the beginning of the agricultural year, viz. July $\mathrm{I}$, with departures from the average, the mean temperature, pressure, and prevail ing winds, and the extremes of temperature. Detailed hourly values of declination, horizontal force, and vertical force as recorded at the Central Magnetic $\mathrm{Ob}$ servatory at Pilar (lat. $3 \mathrm{I}^{\circ} 40^{\prime} \mathrm{S}$., long. $63^{\circ} 53^{\prime} \mathrm{W}$.) also appear, along with a summary of the seismic phenomena recordet at several points with the Milne or Bosch-Omori seismographs.

NO. $25 \mathrm{I} 7$, VOL. IOO]
The hydrometric branch of the service gives in each number of the Boletin the daily height of the principal rivers and lakes of the Republic as observed at fiftyeight places, with the departure from the average, also a special study month by month of the conditions at an individual station. So far the discussions refer to gauges at various points on the River Parana, where there are more than thirty years' observations available. Various interesting articles by members of the staff appear from time to time, and it is to be hoped that the prompt issue of meteorological data initiated by $\mathrm{Mr}$. Wiggin, director of the Argentine service, will extend to other South American weather bureaux.

\section{THE NEEDS OF OUR EDUCATION AT THE PRESENT DAY, WITH SPECIAI REFERENCE TO SCIENCE TEACHING. ${ }^{1}$}

FARLY in the past year a work was published E by a recently retired Ambassador which was understood in a special way to reflect the opinion of the Foreign Office. In this book he set forth the "necessary qualifications" for the diplomatic career, which in his opinion were "good birth, good breeding, good looks, and good health," and went on to say :"Science is not necessary. Geography beyond elementary notions is not of great value. The diplomatist will acquire what geographical knowledge he needs of the country to which he is appointed while residing at the post. Few men can lnow it in sufficient detail beforehand."

We drifted into this war through sheer lack of expert knowledge of foreign countries and foreign languages. We have muddled and misconducted our war operations on sea and land through lack of expert knowledge, of science, on the part of those commanding at home, and sometimes-happily not always-of those commanding abroad. If by the proverbial good luck which saves Great Britain ever and again; if, still more, by the unparalleled bravery of our men in all branches of the combatant Services, by their innate common sense and coolness, and by the occasional streak of genius among their leaders, which not even a War Office or an Admiralty can occlude, we are sufficiently victorious to make peace on satisfactory terms, we shall need more than ever to reform our system of education and the general curriculum to be applied in all schools to the children and youth of both sexes. We shall not, I believe, conquer the Germans sufficiently in this round to be sure they will remain in the sphere allotted to them. We shall at best be able with the help of our Allies to turn them out of France, Belgium, and Italy. Serbia and Rumania, and leave them temporarily exhausted behind a frontier they onlv intend to respect until they regain strength. The one sure way to beat the Germans and keep them in their place is to become better educated than they are, and apply our new education to developing the resources of our own land and of the four or five million square miles in the tropics dependent on the London Government for direction.

Prior to the war, because of our contempt of a scientific education, we offered little or no inducement to our young men and women to serve the Home Country and the Empire in the application of science to industry, commerce, and the enlargement of the nationàl intelligence. Therefore, we had to recruit our science teachers frequently from Germany. A great influx of clever men came to Britain from Germany under the ægis of the Prince Consort and from

1 From the presidential address delivered hefore the Association of PublicSchool Science Masters on 'January 8 by Sir H. If. Johnston, G.C.M.G., K.C.B. 
the awakened interest in art and science he left behind him. They became scientific pioneers in African exploration, professors of philology, of Sanskrit, of Celtic languages, of forestry, botany, zoology, chemistry, and history. They excelled in Oriental studies, in botany, and in chemistry, and rendered yeoman service to British industrial and mental development. Most of them are dead-happily dead before this horrible war revealed the dreadful, the unforgivably cruel side of Imperial Germany. A few are pensioned off, but their names are indelibly inscribed in the history of the British Empire, if that history be truly written. A few have returned to Germany. But never again, within the lifetime of the youngest man present, shall we send to Germany for instructors in any branch of learning.

Consequently, it is more than ever vitally necessary that we should reorganise our education, and produce as home-bred articles all the botanists, philologists, foresters, zoologists, entomologists, chemists, astronomers, translators of Oriental manuscripts, and musicians we require for our home needs and for the Empire dependent on our initiative. We shall not do this efficiently with our existing ideals of education at the great and small schools.

But we require not only to train British biologists, astronomers, ethnologists, philologists, historians, chemists, and a hundred other diverse types of specialists, but equally we need to give a glimmer, a general idea of these branches of science to all the people of the realm. Geography must bulk largely in popular education; some idea should be given of the earth's age and struoture; elementary notions of astronomy, zoology, and botany are highly necessary to the mental equipment of the masses; and ethnology is of equal importance with geography. The history of Great Britain and Ireland should be taught intelligibly and truly, not in the Mrs. Markham style, nor with the prejudices of Macaulay or Father Benson. Something of human anatomy and much about the laws of health should be in the curriculum of even the humblest school. An elementary knowledge of arithmetic and a thorough knowledge of the English language-its origins, its right conventional pronunciation, and its weird and wicked orthography; an introduction to the masterpieces of English literature; smatterings of Latin, Greek, and French-sufficient to understand the part these languages have played in the formation of our vocabulary; a generalised explanation of electricity and the simplest and most important facts of chemistry: these, it seems to me, with the teaching of a good handwriting and the clear expression of thoughts on paper and a little freehand drawing, are the essential subjects of the basic education which should be given to every child in the kingdom between the ages of six and fourteen.

Building on such a base, we can then branch out along the lines of specialist education: Shorthand, after longhand; the phonetic writing of English, after the preposterous artificiality of conventional spelling; foreign languages after our own; drawing and painting for those who incline to the pictile arts; music for all who are musical; anthropology and ethnology in their diverse ramifications for the future traveller, clergyman, administrator, or police-court magistrate; geometry, geodesy, mechanics, hydrostatics, and physics, and the higher mathematics for the predestined surveyor, builder, engineer, or astronomer; chemistry and agriculture, animal pathology for the farmer-in-grain; chemistry, again, and all the outgrowths of that mighty chapter in the New Bible for the intended manufacturer and tradesman; ballistics for the cadet; botany, entomology, sociology, modern history, law, and languages for the future statesman; NO. 2517 , VOL. IOO] and the differential calculus for those who crave an opportunity of applying it to some more practical purpose than merely passing as Senior Wrangler.

Education, it seems to me, comes under three heads : (I) That which deals with the necessities of man's body -gymnastics, training of the eye and ear, the development of the muscles, skill with weapons or utensils, the strengthening of the nerves, the making of each girl and boy into as healthy and fit a member of the community as is possible; the teaching of all the mechanical and constructive arts that go to feeding our bodies and minds, sheltering us, transporting us from place to place, and clothing us. (2) That which supplies the requirements of man's mind, all useful learning regarding the past, the place of our planet in the Cosmos, the other forms of life that share the earth with man, the interpretation of the great New Bible-in short, the Book of the Eanth-itself, which we are just learning to read, and those other lesser books, the products of the human mind; not only the documents left to us from the pre-Christian Mediterranean world, but also the great literatures of India, of Scandinavia, of China and Japan, of Renascent Italy, England, France, of the Aztecs in Mexico, and of the Semitic and Hamitic peoples. (3) That of the education of the soul.

This last is a much-abused word, the precise meaning of which no one can define to the liking of his neighbour. It is the imponderable, "insaisissable," imperishable spirit of the race which we also call "character" and "disposition"; which is referred to poetically as "heart" in contradistinction to "head." It is almost universally agreed that the education of the impressionable young cannot be confined to the cultivation of muscles and the steadying of nerves, to the care of the teeth and the removal of adenoids, to the initiation into the mechanical arts and the decorative arts; nor to the filling of the mind with an encyclopædia of useful information. You have, in addition to caring for mind and body, to impart such education as mavhere with great, there with only partial, success-turn the raw material of your pupils into good men and women, honest servants of the State, enthusiastic patriots, and law-abiding citizens, obeying, however, wise and humane laws which they are competent to frame or to understand.

Into this third great branch of education science, founded on demonstrable truth, alone must enter; superstition must be banned. The scientific basis and authority for temperance and chastity must be explained; children must be shown that wrongdoing against one's self or the community does not pay in the long run-that against one's own body and mind it is rapidly punished; that against the community not only are there unpleasant consequences through the enforcement of laws which we have made for the protection of the community, but also that the wrongdoer himself would suffer in security and happiness were there no such laws.

\section{THE METEOROLOGICAL RESOURCES OF THE EMPIRE. ${ }^{1}$}

T $\mathrm{N}$ many directions steps are being taken to survey the resources of the Empire and to plan how these may best be utilised in the general reconstruction which must undoubtedly be taken in hand on the cessation of hostilities. In meteorology the same should be done, for within the Empire we may meet every type of climate. The great Overseas Dominions, India, the Colonies, and especially the oceanic islands, not only afford the means for extend-

1 Abstract of the presidential address delivered before the Royal Meteorological Society on January 16 by Ma or H. G. Lyons, F.R.S. 